\title{
The Impact of English on the Economic Development of the Philippines
}

\author{
Shigeru Ozaki ${ }^{1 *}$ \\ ${ }^{\mathrm{T}}$ Doshisha University, Karasuma-Higashi-iru, Imadegawa-dori, Kamigyo-ku, Kyoto-shi, Kyoto, Japan \\ *Corresponding Author \\ Shigeru Ozaki
}

Article History

Received: 22.11.2021

Accepted: 26.12 .2021

Published: 03.02.2022

\begin{abstract}
English is commonly used as an official language, a second language for business and commerce, as well as a medium of instruction in Outer Circle countries, including the Philippines. There have been studies about the impact of the English language on the economy of certain Outer Circle countries; however, no existing research has presented a comprehensive picture of its impact on the Philippines, which is renowned for excellence in industries that have developed based on Filipinos' high English proficiency, such as English-speaking call centers and both online and offline schools that teach English as a second language (ESL). Therefore, this article comprehensively describes the relationship between the English language and the economy of the Philippines and explores its associated problems. First, the article briefly explains the history of English education in the Philippines to demonstrate why a large proportion of its population is proficient in English. Second, it focuses on Filipinos' English proficiency by examining their average scores on international standardized English tests and the Business English Index. Furthermore, it reviews the literature that investigates their evaluation of their own English as well as their awareness of the importance of English in their workplaces. Third, it examines English-based industries: call center and ESL industries. Finally, it discusses the problems of using English as a medium of instruction and the exploitation of the Philippines' inexpensive labor force in these English-based industries by developed countries.
\end{abstract}

Keywords: The Philippines, English, economy, call centers, ESL, exploitation, English as a medium of instruction.

\section{INTRODUCTION}

English has become an international language, and many governments are promoting its study to ensure their national prosperity and development (Erling \& Seargeant, 2013). English is employed as a lingua franca, especially in business (Wu, 2013) and science (Drubin, D. G. \& Kellogg, D. R., 2012). Thus, the English language is integral to economic development (British Council, 2013; Chaudhari, n.d.; Shefu \& Shittu, 2015), and many people worldwide study English out of economic necessity (McCormick, 2013).

Some researchers have investigated the relationship between English proficiency and economic development (Arcandi \& Grin, 2013; Azam et al., 2010; Erling et al.,2015; McCormick, 2013; Ozaki, 2018a) and prosperity (Ozaki, $2018 \mathrm{~b}$ ), in both regional and global contexts. Others investigated this relationship by focusing on particular countries or areas, such as India (Meganathan, 2011), Pakistan, (Shamim, 2011), Africa (Williams, 2013), Bangladesh (Erling et al., 2013), and Sub Saharan Africa (Rea-Dickinz et al., 2013). Thus far, there has not been much Philippines-based research on this issue; therefore, this article attempts to provide an overview of the impact of the English language on the economy of the Philippines. Furthermore, it addresses two problems related to the link between English and economic development: the use of English as a medium of instruction (EMI) and excessive dependence on other countries. This would lead both policymakers and implementers to reconsider the role of the English language and their approaches to economic development.

\section{Brief History of English in the Philippines}

The Philippines was colonized by the U.S.A. in 1898, and English was introduced and spread throughout the country upon the establishment of the public education system in 1901 (Bautista, 2001). American teachers sent to the Philippines by the U.S. Government, known as Thomasites, were assigned to elementary schools; thus, English became

Copyright $\odot \mathbf{2 0 2 2}$ The Author(s): This is an open-access article distributed under the terms of the Creative Commons Attribution 4.0 International License (CC BY-NC 4.0) which permits unrestricted use, distribution, and reproduction in any medium for noncommercial use provided the original author and source are credited.

(C) South Asian Research Publication, Bangladesh $\quad$ Journal Homepage: www.sarpublication.com 20 
the medium of instruction (Bernardo, 2008; Kawahara, 2005; Martin, 1999). They also trained Filipino teachers to be able to teach in English (Misch, 2013), and consequently Filipino teachers currently teach students English and various subjects in English.

\section{High English Proficiency of Filipinos}

There are specific test results that illustrate the high English proficiency of the Filipinos: The average TOEFL iBT score of the Filipinos was 88/120 in 2018, which was the sixth highest out of 36 counties in Asia (Educational Testing Service, 2019). Additionally, 77\% of the IELTS test-takers in the Philippines obtained a score of 6.5 or over in 2018 (IELTS, 2019). These TOEFL score and IELTS band would grant admission to universities in English-speaking countries. Another study highlighted their ranking on the EF English Proficiency Index, in which the Philippines is ranked 18th out of 112 countries (Education First, 2021). The Business English Index (GlobalEnglish, 2013) investigated more than 212,000 people who were subscribing to the English learning service offered worldwide by GlobalEnglish, a company that delivers business English learning solutions and productivity tools, and indicated that the Filipinos' business English proficiency is the highest among non-English speaking countries. However, it should be noted that these results do not always accurately represent the average English proficiency of the whole population since they are based on a relatively small number of test-takers (Ozaki, 2018a, b).

Nakahara (2005) investigated 121 native Tagalog speakers' awareness of their command of English and found that they evaluated their English ability as an 82.85 out of 100 on average (Listening: 83.41, Speaking: 75.40, Reading: 90.00, Writing: 82.60). He later conducted the same study on 216 Japanese and 102 Filipino individuals (Nakahara, 2008). The self-evaluated listening, speaking, reading, and writing scores of the Japanese participants were 30.15, 26.63, 36.82 , and 27.44, respectively. On the other hand, the self-evaluated listening, speaking, reading, and writing scores of the Filipino participants were 89.01, 84.30, 92.16, and 88.89, respectively. These scores indicated that Filipinos evaluated their own English skills quite highly. However, it should be noted that these two studies were solely based on selfreported measures, and no valid and reliable measurement was used. Therefore, their actual English proficiency might not necessarily match these results. Furthermore, it investigated only a limited number of Tagalog speakers, despite there being many native speakers of other languages in the Philippines.

Although the validity of the existing evidence of Filipinos' high English proficiency is somewhat questionable, the fact that the country has the largest number of English-speaking call centers (Keitel, 2009) is indicative of their strong command of the language. Bajaj (2011) stated that the Philippines has become the hub of the call center business owing to its large population of young people who speak English fluently without a strong foreign accent.

\section{Importance of English in the Filipino Workplace}

Nakahara (2008) researched into the importance of English in the workplace in the Philippines and Japan; he revealed that over $80 \%$ of the 102 Filipino respondents used English in the following seven fields of their work: meetings, conversations with colleagues, emails to colleagues, company documents, negotiations with business partners, emails to business partners, and documents for business partners. In contrast, fewer than $5 \%$ of the Japanese respondents reported that they were using the language in these seven fields.

English is also important for many Filipinos who wish to work abroad owing to the nation's weak economy (Nakahara, 2006). The total amount of money that overseas Filipino workers (OFWs) sent to the Philippines in the first half of the year 2002 was approximately one-third of the annual government revenue for 2004 (Nakahara, 2006). Between April and September 2018, the total remittance sent by the approximately 2.3 million OFWs worldwide was 235.9 billion pesos (US\$4,659,476,748) (Philippine Statistics Authority, 2019). However, no data is available regarding how many of them actually use English on a daily basis in their workplaces.

\section{Two Major English-based Industries}

Business process outsourcing is a top contributor to the economy of the country (Schmidt, 2021), and it is based on Filipinos' high English proficiency (Cabigon, 2015). Recently, the necessity for Filipinos to have a strong command of English has dramatically increased because of "the development of the offshoring and outsourcing (O\&O) industry," especially "contact or call centers" (Keitel, 2009, p. 3). The Philippines has the largest number of call centers in the world owing to its large English-speaking population (Keitel, 2009; Bajaj, 2011), and around 1.3 million Filipinos work as call center agents (Mugra, 2021). "Entry-level call center agents often receive salaries that are double the norm$\$ 400-\$ 600$, as opposed to $\$ 200-\$ 300$, a month - in addition to health insurance and performance bonuses" (Murga, 2021, para. 3). This demonstrates the strong impact of the English language on the economy of the Philippines.

The other English-based industry is teaching English as a second language (ESL) (Cabigon, 2015). Especially remote English language education is an important part of the Philippines' O\&O industry (Keitel, 2009). In China, the popularity of Filipino teachers of English has been increasing, and their online schools alone are planning to hire 100,000 
more Filipino teachers (Yao, 2019). Several online English schools that hire Filipino teachers can be found on the Internet quite easily. In addition, many English schools for foreigners exist in the Philippines (Ozaki, 2016), and they are also considered part of the O\&O industry since foreign nationals own most of them. Learning English in the Philippines has gained greater popularity (Haisa, 2016) owing to its low cost (Brock, 2015; Haisa, 2016; McGeown, 2012) and Filipinos' high English proficiency (Cabigon, 2015; Chavez, 2014; Ozaki, 2011; GlobalEnglish, 2013). English learners have been shifting to the Philippines from Inner Circle countries such as the United Kingdom, the U.S.A, Canada, Australia, and New Zealand (McGeown, 2012). For instance, approximately 100 Japanese junior and senior high schools sent their students to the Philippines to study English in 2017 ("More Japanese," 2018, March 5). Filipino teachers' English proficiency is utilized also when they teach outside the Philippines. Although it is not clear whether they teach only English, 1821 (Philippine Overseas Employment Administration, n.d.) and 1328 (Philippine Overseas Employment Administration, n.d.) teachers from the Philippines were sent to diverse countries, where they taught in English, in the years 2016 and 2017 respectively.

\section{Problems Related to the Two English-Based Industries 6.1 Excessive Dependence on Developed Countries}

The heavily English-influenced industries in the Philippines are excessively dependent on more developed countries that occasionally exploit the inexpensive labor force of the country. For example, call centers as well as both online and offline English schools are typically owned by foreign companies or individuals. The country's reliance on more developed countries occurs because of its relative economic inferiority and poverty; however, wage inflation, escalating employee attrition, and increasing real estate costs are now a problem in the Philippines (White, 2018). Thus, the country may not be able to maintain its status as the capital of the O\&O industry. Therefore, it needs to find a way to become more independent by effectively utilizing the English proficiency of its population. For example, it should advance technology and export products to other countries. However, there is a possibility that EMI-the primary source of their high English proficiency_-might be hindering such development, as the next subsection explains.

\subsection{English as a Medium of Instruction}

The high English proficiency of Filipinos results from the fact that they use the language as an official language, second language, and medium of instruction. However, EMI could be a double-edged sword. Although it can dramatically improve the populace's English proficiency, it might simultaneously hinder technological advancement and economic development. Some researchers (Ramirez, Yuen, \& Ramey, 1991; Thomas \& Collier, 1997; Walter \& Dekker, 2011) found that minority language students who received education in their first language displayed greater academic achievement than those who were educated in their second or third language, which was often English. The level of Filipino students' academic achievement in math and science is not as high as that of their Japanese counterparts' (Nakahara, 2011); a reason is that the Filipinos usually study these subjects in English, which is not their mother tongue (Yanagihara, 2007). It must be extremely difficult for children to improve their analytical, critical, creative, and logical thinking abilities to a high level in a language that they cannot completely understand or communicate in. Consequently, they might find it difficult to thoroughly understand complex theories and develop them further or apply them practically. Given this disadvantage of adopting EMI, the Department of Education in the Philippines has implemented the Mother Tongue Based Multilingual Education policy to educate children in their mother tongues to facilitate the development of their cognitive and academic abilities (Burton, 2013).

Various disadvantages of utilizing EMI have been found in different parts of the world. In Zambia, using English as an educational language negatively influenced primary students' reading and arithmetic skills (Rassool, 2013). Melitz (2008) found that employing EMI led to a high illiteracy rate in Pakistan owing to a lack of qualified teachers and resources, especially in rural areas. Ricento (2015) indicated the correlation between the national literacy rate and its gross domestic product (GDP) as well as other economic and social development metrics. This happens because people need to be literate to acquire knowledge and skills that are necessary for economic and social development. Furthermore, Outer Circle countries, which utilize English as an official, second and/or main medium of instruction, were found to be inferior in terms of both economic development (Ozaki, 2018a) and prosperity (Ozaki, 2018b) in comparison to Expanding Circle countries, where English is not used in people's daily lives. As these examples illustrate, English could be an obstacle to technological, economic, and social progress. If adopting EMI continues to interfere with the development of Filipinos' knowledge, skills, and abilities that are necessary for such advancement, companies from advanced countries will keep on exploiting the Filipino workers who have a good command of English.

\subsection{Investigation of the Economic Development in Singapore as a Clue for a Possible Solution}

A clue for a possible solution is to investigate the economic development in Singapore, which is highly developed even though it is also located in Southeast Asia and adopts English as an official, second, and educational language due to the colonization by Britain. Examining what this country has been doing to develop its economy might lead to identifying effective ways to utilize English and facilitate independent economic development that does not involve exploitation at the hands of more advanced countries. It does not have as many call centers of companies from English- 
speaking countries or online/offline English schools as the Philippines does, yet its GDP per capita was the fourth highest among 190 countries, whereas that of the Philippines was 115th (Worldometer, 2017). Furthermore, Singaporean students obtained the second-highest score on the reading, math, and science tests of the Programme for International Student Assessment (PISA) (Schleicher, 2019), which proves that their knowledge and skills in these domains are strong. In contrast, Filipino students' scores were very low on the PISA. Their scores were the lowest among all participating nations on the reading test and the second lowest on the math and science tests (Schleicher, 2019). Thus, the Philippines might be able to learn from Singapore how to develop its economy while utilizing its populace's high English proficiency in addition to many other factors.

\section{CONCLUSION}

Although the English language greatly contributes to the Philippines' economy, especially through the call center industry and ESL industry, the excessive dependence on developed countries and the disadvantages of EMI are major challenges for the nation. In order to solve these problems, both policy makers and implementers need to reconsider their approaches to improving the country's economy and people's English proficiency. For example, English should be utilized for technological advancement that would lead the Philippines towards more independent economic development. A potential avenue to address the problems could be to identify how Singapore, which was also once colonized by an English-speaking country and adopted English as an official, second, and educational language, managed to become one of the most advanced and wealthiest countries in the world.

\section{REFERENCES}

- Arcandi, J. L., \& Grin, F. (2013). Language in economic development: Is English special and is linguistics fragmentation bad? In E. Erling \& P. Seargeant (Eds.), English and development: Policy, pedagogy and globalization (pp. 243-266). Bristol, UK: Multilingual Matters.

- Azam, M., Chin, A., \& Prakash, N. (2010). The returns to English-language skills in India. Economic Development and Cultural Change, 61(2), 335-367

- Bajaj, V. (2011, November 25). A new capital of call centers. The New York Times. Retrieved from https://www.nytimes.com/2011/11/26/business/philippines-overtakes-india-as-hub-of-call-centers.html

- Bautista, M. L. (2001). Studies of Philippine English: Implications for English language teaching in the Philippines. Journal of Southeast Asian Education, 2(2), 271-295.

- Bernardo, A. B. I. (2008). English in Philippine education: Solution or problem. In M. L, S. Bautista, \& K. Bolton (Eds.), Philippine English: Linguistics and literacy perspectives (pp. 29-48). Hong Kong, China: Hong Kong University Press.

- British Council. (2013). The English effect. Retrieved from https://www.britishcouncil. Org/sites/default/files/ english-effect-report-v2.pdf

- Brock, A. (2015). Philippines attracts English learners on a budget. VOA. Retrieved from http://learningenglish. voanews.com/a/philippines-attract-eanglish-learners-on-a-budget/2706062.html

- Burton, L. A. (2013). Mother tongue-based multilingual education in the Philippines: Studying top-down policy implementation from the bottom up [Unpublished doctoral dissertation]. University of Minnesota, Minneapolis, U.S.A.

- Cabigon, M. (2015). State of English in the Philippines: Should We Be Concerned? British Council. Retrieved from https://www.britishcouncil.ph/teach/state-english- philippines-should-we-be-concerned-2

- Chaudhari, S. K. (n.d.). Language skills and economic prosperity. Tactful Management Research Journal. Retrieved from http://oldtm.lbp.world/SeminarPdf/192.pdf

- Chavez, A. (2014, January 10). What Asia can learn from Philippines about English education. Huffington Post. Retrieved from http://www.huffingtonpost.com/amy-chavez/what-asia-can-learn- from-_b_4572991.html

- Drubin, D. G., \& Kellogg, D. R. (2012, April 15). English as the universal language of science: opportunities and challenges. Mol Biol Cell, 23(8). Retrieved from https:// www. ncbi.nlm.nih.gov/pmc/articles/PMC3341706/

- Education First. (2021). The world's largest ranking of countries and regions by English skills. Retrieved from https://www.ef.com/wwen/epi/

- $\quad$ Educational Testing Service. (2019). Test and score data summary for TOEFL iBT Test: January 2018 - December 2018 test data. Retrieved from https://www.toefl-ibt.jp/dcms_media/other/toefl_data.pdf

- $\quad$ Erling, E. J., Hamid, M. O., \& Seargeant, P. (2013). Grassroots attitudes to English as a language for international development in Bangladesh. In Erling, E. J. and Seargeant, P. (Eds.), English and development: Policy, pedagogy and globalization. Critical Language and Literacy Studies (pp. 88-110). Bristol: Multilingual Matters.

- Erling, E. J., \& Seargeant, P. (2013). Introduction: English and development. In E. J. Erling \& P. Seargeant (Eds.), English and development: Policy, pedagogy and globalization (pp. 1-20). Bristol, UK: Multilingual Matters.

- $\quad$ Erling, E. J., Seargeant, P., Solly, M., Chowdhury, Q. H., \& Rahman, S. (2015). English for economic development: A case study of migrant workers from Bangladesh. ELT Research Papers, 15(03). Retrieved from http://oro.open.ac.uk/44301/1/2999_BC_OU\%20Eltra\% 20Booklet_05b.pdf 
- GDP per Capita. (2017). Worldometer. Retrieved from https://www.worldometers.info/gdp/gdp-per-capita/

- GlobalEnglish. (2013). Heightened urgency for business English in an increasingly global workforce: A look at the 2013 Business English Index \& globalization of English research. Retrieved from http://static.globalenglish. com/files/GlobEng_BEIreport\%202013_EN_A4_FINAL.pdf

- Haisa, A. (2016). Studying English in the Philippines and its influence on language attitudes: Analysis of interview data from Japanese learners. Ryuиgaku Коигуии, 62, 7-10.

- IELTS. (2019). Demographic data 2019. Retrieved from https://www.ielts.org/for-researchers/test-statistics/ demographic-data

- Kawahara, T. (2005). A comparative study of the Thomasites and the oyatoi gaikokujin: Foreign teachers and their language teaching. In D. T. Dayag \& J. S. Quakenbush (Eds.), Linguistics and language education in the Philippines and beyond: A Festschrift in honor of Ma. Lourdes S. Bautista (pp. 305- 319). Manila, Philippines: Linguistic Society of the Philippines.

- $\quad$ Keitel, R. S. (2009). Innovation in borderless distance learning of English. Paper presented at the 13th UNESCOAPEID International Conference World Bank-KERIS High Level Seminar on ICT in Education.

- Martin, P. I. M. (1999). Language and institution: Roots of bilingualism in the Philippines. In M. Lourdes, S. Bautista, \& G. O. Tan (Eds.), The Filipino bilingual: A multidisciplinary perspective (Festshrift in honor of Emy M. Pascasio) (pp. 132-136). Manila, Philippines: Linguistic Society of the Philippines.

- McCormick, C. (2013, November 15). Countries with better English have better economies. Harvard Business Review. Retrieved from https://hbr.org/2013/11/countries-with-better-english-have-better-economies

- McGeown, K. (2012). The Philippines: The world's budget English teacher. Retrieved from http://www.bbc.com/ news/business-20066890

- $\quad$ Misch, M. (2013). Philippine English. Santa Cruz, CA: Grin Verlag.

- Meganathan, R. (2011). Language policy in education and the role of English in India: From library language to language of empowerment. In H. Coleman (Ed.), Dreams and Realities: Developing Countries and the English Language (pp. 57-86). London: British Council.

- Melitz, J. (2008). Language and foreign trade. European Economic Review, 52, 667-699.

- More Japanese head to Philippines to study English on a budget. (2018, March 5). The Japan Times. Retrieved from https://www.japantimes.co.jp/news/2018/03/05/national/japanese-head-philippines-study-english-budget/

- Murga, A. F. (2021, April 28). The everyday racism of offshore call centers. Rest of World. Retrieved from https://restofworld.org/2021/call-centers-racism/

- Nakahara, K. (2005). Review of Some Literatures and Results of Survey on English and Filipino in the Philippines. Keizaikei, The Society of Economics, Kanto Gakuin University, 225, 1-17.

- Nakahara, K. (2006). The socio-linguistics situation in the Philippines and the future of English and Filipino in the country. Nature-people-society: Science and the Humanities, Kanto Gakuin University, 40, 33-49.

- Nakahara, K. (2008). Importance of English proficiency in business: Situations in Japan and in the Philippines. Kanto Gakuin Daigaku Keizaigakkai Kenkyuu Ronsyuu Keizaikei, 234, 41-59.

- Nakahara, K. (2011). Some keys to improving Japanese English education: What parts of the Philippines' education system should we follow? Kanto Gakuin Daigaku Keizaigakubu Kyoyo Gakkai Shizen Ningen Shakai, 50, $27-53$.

- Ozaki, S. (2011). Learning English as an international lingua franca in a semi-English-speaking country: The Philippines. The Asian EFL Journal, 53, 51-60.

- Ozaki, S. (2018a). English proficiency and economic development: Comparing the Expanding Circle and the Outer Circle. Takushoku Language Studies, 138, 39-72.

- Ozaki, S. (2018b). English proficiency and prosperity: Comparing the Outer Circle and the Expanding Circle. Proceedings of 12th International Conference on Language, Education and Innovation (ICLEI) 2018. Retrieved from https://icsai.org/proceedings/ 12iclei-038/

- Philippine Overseas Employment. (n.d.). Teachers by destination by gender: New hires Y2016. Retrieved from https://www.poea.gov.ph/ofwstat/teachers/2016\%20teachers. Pdf

- $\quad$ Philippine Statistics Authority. (2019, April 30). Total Number of OFWs Estimated at 2.3 Million (Results from the 2018 Survey on Overseas Filipinos). Retrieved from https://psa.gov.ph/content/total-number-ofws-estimated-23million-results-2018-survey-overseas-filipinos

- Ramirez, J. D., Yuen, S. D., \& Ramey, D. R. (1991). Final report: Longitudinal study of structured English immersion strategy, early-exit and late-exit transitional bilingual education programs for language-minority children. Retrieved from https://ncela.ed.gov/files/rcd/BE017748/Longitudinal_Study_Executive_Summary.pdf

- Rassool, N. (2013). The political economy of English language and development: English vs. national and local languages in developing countries. In E. J. Erling \& P. Seargeant (Eds.), English and development: Policy, pedagogy and globalization (pp. 45-67). Bristol, UK: Multilingual Matters.

- $\quad$ Rea-Dickinz, P., Khamis, Z. K., \& Olivero, F. (2013). The relationship between English medium instruction and examining and social and economic development: A sub-Saharan African case study. In E. J. Erling \& P. Seargeant (Eds.), English and development: Policy, pedagogy and globalization (111-140). Bristol, UK: Multilingual Matters. 
- Ricento, T. (2015). "English,” the global lingua franca? In T, Ricento (Ed.). Language policy \& political economy: English in a global economy (pp. 276-304). Oxford: Oxford University Press.

- Schleicher, A. (2019). PISA 2018: Insights and Interrelations. Retrieved from https://www. oecd.org/pisa/PISA\% 202018\%20Insights\%20and\%20Interpretations\% 20FINAL\%20PDF.pdf

- Schmidt, K. (2SEPTEMBER 9, 2021). The Philippines: Emerging From a Sea of Language Learning Destinations. Bridge. Retrieved from https://bridge.edu/tefl/blog/the-philippines-emerging-from-a-sea-of-languagelearningdestinations/?utm_source=rss\&utm_medium = rss\&utm_campaign= the-philippines-emerging-from-a-seaof-language-learning-destinations

- Shamim, F. (2011). English as the language for development in Pakistan: Issues, challenges and possible solutions. In H. Coleman (Ed.), Dreams and Realities: Developing Countries and the English Language (pp. 291-310). London: British Council.

- Shefu, H., \& Shittu, K. O. (2015). The bridge to economic prosperity: The role of English language communication in entrepreneurship. International Journal of Humanities and Social Science, 5(7). 189-195.

- Thomas, W. P., \& Collier, V. P. (1997). A national study of school effectiveness for language minority students' long-term academic achievement. Retrieved from https://escholarship.org/uc/item/65j213pt

- Trudgill, P. \& Hannah, J. (1994). International English: A guide to the varieties of standard English. New York: Edward Arnold.

- Walter, S., \& Dekker, D. (2011). Mother tongue instruction in Lubuagan: A case study from the Philippines. International Review of Education, 57(5-6), 66-7683.

- White, K. (2018, October 22). Largest call center employers in the Philippines indicate the power of global site selection strategies. Site Selection Group. Retrieved from https://info.siteselectiongroup.com/blog/largest-callcenter-employers-in-the-philippines-indicate-the-power-of-global-site-selection-strategies

- Williams, E. (2013). Political perspectives on language policies and development in Africa. In E. J. Erling \& P. Seargeant (Eds.), English and development: Policy, pedagogy and globalization (pp. 68-78). Bristol, UK: Multilingual Matters.

- Wu, Y. (2013). Business English as a lingua franca (BELF). International Education Studies, 6(10), 130-138.

- Yao, L. (2019). Philippines offers low-cost solution to China's growing English teacher demand. Global Times. Retrieved from https://www.globaltimes.cn/content/1135986.shtml

- Yanagihara, Y. (2007). A study of bilingual education in the Philippines: Difference in pupils' degree of understanding between learning mathematics in Cebuano and English. Keiai Journal of International Studies, 19. 175-201.

CITATION: Shigeru Ozaki (2022). The Impact of English on the Economic Development of the Philippines. South Asian Res J Art Lang Lit, 4(1): 20-25. 